2. Obstetric nurse shall only assist labour by external means, whether by manipulations, or medicines, or instruments, or appliances.

3. Aseptic principles, as taught, shall be carried out by obstetric 3. Aseptic principles, as taught, shall be carried out by obstetric
nurse both as regards parts of patient, externally, and parts of obstetric

urse herself (hands, dress, appliances).

4. Obstetric nurse to douche passages of patient only after direction of medical practitioner, with approved appliances or instruments that are subject to medical practitioner's inspection on his visit.

As an answer to the question regarding responsibility urged by your correspondent, he will observe in the above scheme that an obstetric nurse would be subject to such control and disciplinary influence under an appointed medical practitioner as would render her malpractice rare and liable to the penalty of loss of certificate, to say the least. Nor can the point concerning fragment of placenta be properly advanced in the face of the above scheme. Any substitute for a qualified medical practitioner may leave behind a fragment of placenta-much more the ordinary or even registered midwife.-I am, Sirs, yours faithfully,

London, Jan. 13th, 1900.

HAYDN BROWN.

\section{"PRESCRIBING ALCOHOL versus OUR OWN INTERESTS."}

\section{To the Editors of THE LANGET.}

SIRS,-I shall be much obliged if you will grant me some space to reply to Dr. Coley's remarks upon my views. In the course of a somewhat stormy controversial career I do not know that I have met with misrepresentations quite so complete as those with which he favours me in THE LANCET of Jan. 13th. He says: "According to him the way to secure sobriety for the human race some thousands of years hence is to let alcohol have its own way for the present and (with the aid of those beneficent eliminators of the unfit, poverty, and starvation, and tuberculosis, and crime) get rid of all who have "an inborn capacity for delighting in it." " May I ask Dr. Coley to quote, with due regard to the context, the passage in which $I$ advocated views so atrocious and really so excessively silly? Giving my data, I made two statements of fact which I believe are incontrovertible-at any rate, they are incontroverted. The one that all free and civilised races are now temperate strictly in proportion to the extent they have been weeded out by alcohol; the other that in the future all such races will be temperate in like proportion unless certain measures (which I mentioned) were adopted. Having traced the past of an epidemic I endeavoured to forecast its future and to suggest a remedy. Dr. Ooley thinks it right to inform a possibly horrified public that I advocate the spread of the disease. I am irresistibly reminded of the fat boy in "Pickwick" who was desirous of making the flesh creep.

He says, "Some of us may venture to doubt whether Weissmann's facts are sufficient to support his own theory." But, to quote the memorable words addressed by Sairey Gamp to Mrs. Prig, "Who deniges of it, Betsy?" I myself am of the opinion that Weissmann's doctrines are metaphysical nonsense and I cannot imagine why Dr. Coley will persist in attributing to me a belief in them. I hardly dare venture to suggest that he is perhaps belabouring the wrong philosopher; or to believe that this severe and confident critic has confused Galton's theory of the non-transmissibility of acquired characters with the fantastic superstructures for which alone Weissmann is responsible. If this surmise should unhappily prove correct-and really the more Ithink the more I believe it likely-Dr. Coley will find a deal of information, useful to the scientific critic, in the late Professor Romanes's book "Weissmannism."

May I suggest to him that the doubt he expresses is only an opinion and that mere opinions are not of the slightest value in science? If he will support his opinion with facts and arguments I on my part will cheerfully undertake to deal with them. For reasons I need not enter into this offer is not indicative of very great vanity. He concludes by saying, "But the inverted pyramid of inference which Dr. Reid has tried to balance upon Weissmann's dogma wonld topple over even if the foundation upon which he has rested it were firm as rock." But I have not tried to balance anything on Weissmann's dogma, whatever it may be. Moreover, my opinions were supported by facts and arguments. If instead of misrepresenting and then contradicting conclusions Dr. Coley will destroy the premises, I-well, I shall be infinitely surprised.

Southsea, Jar. 15th, 1900. I am, Sirs, yours faithfully, G. ARchdall Reid.

\section{“DIPHTHERIA AND MILK-SUPPLY : A FILTHY HABIT."}

To the Editors of THB LANOHT.

SrRs, - I confirm Miss Williams's statement in THE LANCET of Jan. 13th as to the dirty and filthy habit of many milkers in the eastern counties who moisten their hands with saliva before seizing the teats in milking. It is quite possible that thus diphtheria bacilli might be introduced into the milk of a cow. On page 199 of Newman's " Bacteria " the suggestion is given of milk becoming contaminated with tubercle in like manner from a milker whilst suffering from tuberculosis.-I am, Sirs, yours faithfully,

William H. HewleTt, M.D., D.P.H. Aberd.

Wivenhoe, Essex, Jan. 15th, 1900.

\section{"A CASE OF SUPRAPUBIC LITHOTOMY : REMOVAL OF TWO VESICAL CALCULI ; RECOVERY." To the Editors of THE LANOFT.}

SrRs,-Allow me to congratulate Mr. Vincent Jackson on his successful case of suprapubic lithotomy in a boy of eight years. At the same time I would like to ask why is it that such a case would hardly be remarked had it been treated by either litholapazy or by lateral lithotomy? I only venture to ask you to permit me to occupy a small amount of your space in writing of this subject, because I have the advantage in forming an opinion of working neither in England nor India. In treating successfully 30 cases of stone at varying ages between two years and 80 years-the calculi weigh ing from six grains to two ounces-I have employed every method and $I$ heartily support Mr. Jackson in his plea for the right of the surgeon to select his operation. But I fear that Mr. Jackson's remark that "litholapaxy is a very easy operation while lateral lithotomy is not" may mislead. $\mathrm{Mr}$. Reginald Harrison, whose keen clinical instinct always directs his knife and whose pen never wanders from the work that his knife has done, is not in favour of the suprapubic operation in children; and although in our art there is no finality it may yet be true that enough work has been done to show that while litholapaxy is seen at its best in children the suprapubic operation has proved itself of all methods in childhood the most dangerous.

I am, Sirs, yours faithfully,

Rio Tinto Hospital, Huelva, Spain, January, 1900.

W. A. MACKAY.

\section{" THE LESSON OF THE INFLUENZA EPIDEMIC",}

To the Editors of THE LANCET.

SIRs,-There is one flaw in the counsels contained in the leading article on the above subject in THE LANCET of Jan. 13th and I fear it is a fatal one. If it be the duty of any person who has been attacked by influenza to seclude himself from contact with his fellows because he is infectious he is naturally entitled to ask to what extent be is to do so and for how long a time. How is his medical attendant to answer this question? If such a question be put in the case of small-pox or scarlet fever or enteric fever, and also, though not with precisely the same degree of certainty, in whooping. cough and measles, the attendant can reply until such or such symptoms or conditions have disappeared. The realisation of this result can, when it occurs, be recognised by the patient himself as well as it can by the medical attend. ant, except, perhaps, when the criterion of freedom from infection is a bacteriological one, as in the case of diphtheria, and it is upon the possibility of this recognition by the patient that his coöperation and that of his friends can be enlisted in maintaining the isolation which his medical attendant prescribes. But what is the criterion of freedom from infection in a person who has had influenza and to what extent and for how long is isolation to be prescribed? It is obvious that in such a case pure dogma, even if there were any base at all for it, is a dangerous aid on which to rest.

But there is another consideration which, apart from that just referred to, must make any attempt at isolation of influenza patients a counsel of perfection so far as the bulk of the public are concerned-it is the anomaly which the disease exhibits in its attacks. It is a fact with which, of 